\title{
Isolation and genotyping of Toxoplasma gondii from pregnant dairy cows (Bos taurus) slaughtered
}

\author{
Isolamento e genotipagem de Toxoplasma gondii em vacas de leite (Bos taurus) prenhas abatidas
}

Madlaine Frigo Silveira Barbosa de Macedo ${ }^{1}$; César Augusto Barbosa de Macedo ${ }^{1}$;

Maria Paula de Carvalho Ewald ${ }^{1}$; Guilherme Felippelli Martins ${ }^{1}$; Dauton Luiz Zulpo';

Ivo Alexandre Leme da Cunha ${ }^{1}$; Alessandra Taroda ${ }^{1}$; Sergio Tosi Cardim ${ }^{1}$; Chunlei Su²; João Luis Garcia ${ }^{1 *}$

${ }^{1}$ Departamento de Medicina Veterinária Preventiva, Universidade Estadual de Londrina - UEL

${ }^{2}$ Department of Microbiology, The University of Tennessee

Received April 27, 2011

Accepted August 11, 2011

\begin{abstract}
The current study aimed to evaluate serology, and isolate and genotype Toxoplasma gondii strains from pregnant dairy cows, slaughtered in an abattoir for human consumption, and their fetuses. Blood from 60 pregnant dairy cows and blood and tissue samples (brain, lung, heart, and liver) from their fetuses were collected and analyzed in a mouse bioassay. Antibodies against T. gondii were observed in $48.3 \%$ of cows and $3.7 \%$ of fetuses (IFAT, titers $\geq 50$ for cows and 25 for fetuses were considered positive). Fourteen fetuses (23.3\%) and six cows (10.0\%) were identified as positive in the bioassay. T. gondii was isolated from a blood sample of a cow older than 4 years old in the $6^{\text {th }}$ month of pregnancy, and from a blood sample of a fetus in the $6^{\text {th }}$ month of gestation. These isolates were identified by polymerase chain reaction (PCR) as being of T. gondii and both strains showed type II alleles for all PCR-restriction fragment length polymorphism (PCR-RFLP) markers tested. T. gondii type II strain from cattle was isolated for the first time in Brazil. The current study also showed that transplacental transmission of $T$. gondii naturally occurs in dairy cows (23.3\%) from Southern Brazil.
\end{abstract}

Keywords: Toxoplasma gondii, cattle, isolation, genotype characterization.

\section{Resumo}

O presente estudo teve como objetivo avaliar a ocorrência de anticorpos, isolar e genotipar Toxoplasma gondii de vacas prenhas abatidas em um matadouro para consumo humano e de seus respectivos fetos. Sangue de 60 vacas gestantes e amostras de sangue e tecidos (cérebro, pulmão, coração e fígado) de seus fetos foram coletados e utilizados para bioensaio em camundongos. Anticorpos contra T. gondii foram observados em 48,3\% das vacas e em 3,7\% dos fetos (foram considerados positivos títulos $\geq 50$ para as vacas e $\geq 25$ para os fetos). Quatorze fetos (23,3\%) e seis vacas $(10,0 \%)$ apresentaram-se positivas para T. gondii ao bioensaio. T. gondii foi isolado de amostra de sangue de uma vaca com mais de quatro anos no $6^{\circ}$ mês de gestação e de amostra de sangue de um feto no $6^{\circ}$ mês de gestaçáo. Por PCR esses isolados foram identificados como sendo de T. gondii e ambas as cepas apresentaram o alelo tipo II em todos os marcadores de PCR-RFLP testados. Esta é a primeira identificação de genótipo tipo II de T. gondii em bovinos do Brasil. Além disso, este estudo mostrou que a transmissão transplacentária de T. gondii ocorre naturalmente em bovinos de leite $(23,3 \%)$.

Palavras-chave: Toxoplasma gondii, bovinos, isolamento, caracterização genotípica.

Toxoplasma gondii is an intracellular parasite that infects a variety of cell types from a wide range of birds and mammals throughout the world, including humans. Human infection occurs by two main routes, ingestion of oocysts and undercooked or raw meat

\section{${ }^{*}$ Corresponding author: João Luis Garcia}

Departamento de Medicina Veterinária Preventiva,

Universidade Estadual de Londrina - UEL,

CP 6001, CEP 86050-970, Londrina, PR, Brazil

e-mail: jlgarcia@uel.br with tissue cysts of the parasite (DUBEY, 1996). The current study aimed to isolate and genotype $T$. gondii from pregnant dairy cows slaughtered for human consumption and their fetuses.

A total of 60 samples were obtained from pregnant dairy cows (Bos taurus) and their fetuses at an abattoir located in the municipality of Presidente Getúlio, Santa Catarina state, southern Brazil. The current study was approved by the Animal Ethics Committee of Universidade Estadual de Londrina (No 018/2009). Blood samples $(5 \mathrm{~mL})$ with EDTA were collected from these 
cows and from their fetuses' heart. White blood cells were separated by centrifugation at $550 \mathrm{~g}$ for 10 minutes, diluted in $1 \mathrm{~mL}$ of antibiotic saline solution $(1,000 \mathrm{U}$ penicillin and $100 \mu \mathrm{L}$ of streptomycin. $\mathrm{mL}^{-1}$ of saline solution) and inoculated subcutaneously into three mice $(0.3 \mathrm{~mL} /$ mouse). Tissues from fetuses, approximately $10 \mathrm{~g}$ of each tissue (brain, lung, heart, and liver) for fetuses $\geq 3$ months of age, and a pool of organs ( $10 \mathrm{~g}$ ) for fetuses $\leq 3$ months were obtained. For tissue digestion the protocol described by Dubey (1998) was used. The result of the mouse bioassay was considered positive when tachyzoites, tissue cysts or anti- $T$. gondii antibodies were detected.

Serum samples were tested by indirect fluorescent antibody test (IFAT), performed according to Garcia et al. (1999), to detect antibodies against $T$. gondii. Sera were considered positive for titers $\geq 1: 50$ for cows and $\geq 1: 25$ for fetuses.

Infected brains and peritoneal liquid from bioassayed mice (where tissue cysts and tachyzoites were observed) had DNA extracted to be tested by polymerase chain reaction (PCR) as described previously (GARCIA et al., 2006). The DNA amplification for T. gondii and Neospora caninum differentiation was performed using the method described by Homan et al. (2000) and Müller et al. (1996), respectively. Genotyping was performed through multilocus PCR-restriction fragment length polymorphism (PCR-RFLP) analysis at 13 markers: SAG2-3' and SAG2-5' (HOWE et al., 1997), SAG3, GRA6 and SAG1, BTUB, L358, c22-8, c29-2, PK1, Apico, SAG2-alt, and CS3 (SU et al., 2006; PENA et al., 2008).

The study variables were analyzed by the chi-square test $\left(\chi^{2}\right)$ with correction of Yates using the Epi Info program (CDC, 6.04b version). We considered as significant a p-value $\leq 0.05$.
Pregnant cows showed a 48.3\% (29/60) seroprevalence for T. gondii. The results of the bioassay are summarized in Table 1 . Sixteen out of 60 (26.6\%) slaughtered pregnant cows, 11 Jersey and five Holstein, were positive in the bioassay either by T. gondii detection in their blood or fetuses. Of these 16 cows, only six (37.5\%) had antibody titers detected by IFAT, and all of them were $\geq 4$ months of pregnancy. $T$. gondii was isolated from the blood of a cow (Nr. 53; brain cysts observed in bioassayed mice) older than 4 years old in the $6^{\text {th }}$ month of pregnancy, and from the blood of a fetus (Nr.103; tachyzoites observed in peritoneal liquid of bioassayed mice) in the $6^{\text {th }}$ month of gestation. The current study detected a $T$. gondii transplacental transmission rate in dairy cows of $23.3 \%(14 / 60)$.

The DNA extracted from brain cysts and tachyzoites isolated in mice were confirmed to be positive for T. gondii and negative for $N$. caninum. Genotyping of both strains (TgBoBrland 2) identified type II lineage for all PCR-RFLP markers tested.

In the current study, two T. gondii strains were isolated, by bioassay in mice, from naturally infected animals, one of them from a pregnant cow and another one from a fetus. Dubey and Thulliez (1993) failed to isolate the parasite from the blood of calves and pregnant cows infected with high load of oocysts. Using the same protocols we were not able to isolate $T$. gondii strains (MARQUES, 2009) from zebu cows. Oliveira et al. (2001) infected B. taurus, B. indicus, and Bubalus bubalis with T. gondii oocysts orally, and described that $B$. taurus were more affected than the other species.

The current finding that $T$. gondii can be transplacentally transmitted in cattle was previously described (CANADA et al., 2002), but it has not been suggested that this parasite is an important bovine abortifacient.

Table 1. Positive results for Toxoplasma gondii by a mouse bioassay performed in slaughtered pregnant dairy cows and their fetuses in the municipality of Presidente Getúlio, Santa Catarina state, southern Brazil.

\begin{tabular}{|c|c|c|c|c|c|c|c|c|}
\hline \multirow{3}{*}{ Cow breed } & \multicolumn{2}{|c|}{ 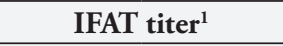 } & \multirow{3}{*}{$\begin{array}{l}\text { Gestation age } \\
\text { (months) }\end{array}$} & \multicolumn{5}{|c|}{ Bioassay of tissues $^{2}$} \\
\hline & \multirow{2}{*}{ Cow } & \multirow{2}{*}{ Fetus } & & \multirow{2}{*}{ Cows $^{3}$} & \multicolumn{4}{|c|}{ Fetus $^{4}$} \\
\hline & & & & & Bl & $\mathrm{Br}$ & $\mathbf{H}$ & Lu \\
\hline 06- Jersey & $\mathrm{N}$ & $\mathrm{N}$ & 6 & - & + & - & - & - \\
\hline 25-Holstein & 100 & $\mathrm{~N}$ & 7 & + & - & - & - & - \\
\hline 34-Jersey & 100 & $\mathrm{~N}$ & 4 & - & - & + & - & - \\
\hline 37-Jersey & 50 & $\mathrm{~N}$ & 6 & - & + & - & + & - \\
\hline 53-Holstein & $\mathrm{N}$ & $\mathrm{N}$ & 6 & $+^{*}$ & - & - & - & - \\
\hline 74-Jersey & $\mathrm{N}$ & $\mathrm{N}$ & 6 & - & - & + & + & - \\
\hline 75-Jersey & 50 & $\mathrm{~N}$ & 7 & - & + & + & - & - \\
\hline 103-Jersey & 50 & $\mathrm{~N}$ & 6 & + & $+^{\mathrm{T}}$ & + & + & + \\
\hline 105-Jersey & 50 & $\mathrm{~N}$ & 7 & + & + & - & - & + \\
\hline 127-Jersey & $\mathrm{N}$ & $\mathrm{N}$ & 5 & - & + & + & + & - \\
\hline 131-Jersey & 25 & $\mathrm{~N}$ & 7 & - & - & - & - & + \\
\hline
\end{tabular}

${ }^{1}$ Indirect fluorescence antibody test; ${ }^{2}$ the mouse bioassay was performed with blood from cows ${ }^{3}$ and fetal tissue samples from blood $(\mathrm{Bl})$, brain $(\mathrm{Br}), \mathrm{heart}(\mathrm{H})$ and lung $(\mathrm{Lu})^{4} . \mathrm{N}=$ negative. Isolation of ${ }^{*}$ brain cysts and ${ }^{\mathrm{T}}$ tachyzoites in peritoneal liquid. ${ }^{+}$Positive; ${ }^{-}$negative. 
We found that only six out of 16 dams detected as positive in the bioassay had antibody titers to $T$. gondii detected by IFAT. This finding is not yet clear and needs to be further explored. There is an established correlation between anti- $T$. gondii antibodies and tissue cysts in sheep and pigs (OPSTEEGH et al., 2010), however, this has not been found in cattle (OPSTEEGH et al., 2011). These authors described that the risk of human infection is higher from seronegative than seropositive cattle based on the fact that they detected DNA from $T$. gondii from negative but not from positive animals. Moreover, infectivity and pathogenicity of $T$. gondii in cattle vary with the strain, and pathogenicity is generally only mild to moderate (FAYER; FRENKEL, 1979). After infection, cattle may eliminate the parasite from their tissues, which is often followed by disappearance of antibodies in some cattle (DUBEY; THULLIEZ, 1993). The factors involved in this natural resistance are not yet known (ESTEBAN-REDONDO; INNES, 1997). Costa et al. (2011) studied pregnant cows and their fetuses from a slaughterhouse in Jaboticabal, southeastern Brazil. They showed an $18 \%$ seroprevalence of anti- $T$. gondii antibodies in cows, however, only low titers of 1:64 were observed. Even when they studied nine cows experimentally infected with oocysts of $T$. gondii the predominant titer was the same.

In the current study a $T$. gondii type II strain was isolated for the first time from cattle in Brazil. Studies using a large number of T. gondii isolates from chickens, cats, and capybaras were performed in Brazil (PENA et al., 2008; DUBEY; SU, 2009; YAI et al., 2009), and similar conclusions were drawn: a) there is no T. gondii type II lineage in Brazil; b) T. gondii type I strains are rare; and c) most strains are not clonal, suggesting recombination and effective transmission of oocysts. It is interesting the fact that multilocus PCR-RFLP genotyping of $T$. gondii strains in our study revealed type II alleles in all genetic markers tested. Dubey et al. (2010) and da Silva et al. (2011), also using multilocus PCR-RFLP genotyping, described type II genotype in chickens from Fernando de Noronha island, and in sheep slaughtered in São Paulo, southeastern Brazil, respectively. Thus, considering these results, the first conclusion is not valid in Brazil. On the other hand, a recent study (FRAZĀO-TEIXEIRA et al., 2011) demonstrated that multilocus DNA sequencing is more accurate than multilocus PCR-RFLP to identify the actual genotypes in T. gondii isolates in regions of the world where genetic diversity is substantial such as Brazil.

\section{Acknowledgements}

\section{J.L. Garcia is recipient of CNPq fellowship.}

\section{References}

Canada, N, Meireles CS, Rocha A, Da Costa JM, Erickson MW, Dubey JP. Isolation of viable Toxoplasma gondii from naturally infected aborted bovine fetuses. J Parasitol 2002; 88(6): 1274-1248.

Costa, GHN, Costa AJ, Lopes WDZ, Bresciani KDS, Santos TR, Esper CR, Santana ÁE. Toxoplasma gondii: Infection natural congenital in cattle and an experimental inoculation of gestating cows with oocysts.
Exp Parasitol 2011; 127(1): 277-281. PMid:20736009. http://dx.doi. org/10.1016/j.exppara.2010.08.005

Da Silva RC, Langoni H, Su C, Da Silva AV. Genotypic characterization of Toxoplasma gondii in sheep from Brazilian slaughterhouses: new atypical genotypes and the clonal type II strain identified. Vet Parasitol 2011; 175(1-2): 173-177. PMid:20970257. http://dx.doi. org/10.1016/j.vetpar.2010.09.021

Dubey JP, Thulliez P. Persistence of tissue cysts in edible tissues of cattle fed Toxoplasma gondii oocysts. Am J Vet Res 1993; 54(2): 270-273.

Dubey JP. Strategies to reduce transmission of Toxoplasma gondii to animals and humans. Vet Parasitol 1996; 64(1-2): 65-70. http://dx.doi. org/10.1016/0304-4017(96)00961-2

Dubey JP. Refinement of pepsin digestion method for isolation of Toxoplasma gondii from infected tissues. Vet Parasitol 1998; 74(1): 75-77. http://dx.doi.org/10.1016/S0304-4017(97)00135-0

Dubey JP, Su C. Population biology of Toxoplasma gondii: what's out and where did they come from. Mem Inst Oswaldo Cruz 2009; 104(2): 190-195. http://dx.doi.org/10.1590/S0074-02762009000200011

Dubey JP, Rajendran C, Costa DGC, Ferreira LR, Kwok OCH, Qu D, Su C, Marvulo MFV, Alves LC, Mota RA, Silva JCR. New Toxoplasma gondii genotypes isolated from free-range chickens from the Fernando de Noronha, Brazil: Unexpected Findings. J Parasitol 2010; 96: 709-712. PMid:20486738. http://dx.doi.org/10.1645/GE-2425.1

Esteban-Redondo I, Innes EA. Toxoplasma gondii infection in sheep and cattle. Comp Immunol Microbiol Infect Dis 1997; 20(2): 191-196. http://dx.doi.org/10.1016/S0147-9571(96)00039-2

Fayer R, Frenkel JK. Comparative infectivity for calves of oocysts of feline. coccidia: Besnoitia, Hammondia, Cystoisospora, Sarcocystis, and Toxoplasma. J Parasitol 1979; 65(5): 756-762. PMid:117090. http://dx.doi.org/10.2307/3280357

Frazão-Teixeira E, Sundar N, Dubey JP, Grigg ME, De Oliveira FCR. Multi-locus DNA sequencing of Toxoplasma gondii isolated from Brazilian pigs identifies genetically divergent strains. Vet Parasitol 2011; 175(1-2): 33-39. PMid:21051148. PMCid:3141217. http://dx.doi. org/10.1016/j.vetpar.2010.09.030

Garcia JL, Navarro IT, Ogawa L, Oliveira RC. Soroprevalência do Toxoplasma gondii em suínos, bovinos, ovinos e eqüinos, e sua correlação com humanos, felinos e caninos, oriundos de propriedades rurais do norte do Paraná, Brasil. Cienc Rural 1999; 29(1): 91-97. http://dx.doi. org/10.1590/S0103-84781999000100017

Garcia JL, Gennari SM, Machado RZ, Navarro IT. Toxoplasma gondii: Detection by mouse bioassay, histopathology, and polymerase chain reaction in tissues from experimentally infected pigs. Exp Parasitol 2006; 113(4): 267-271. PMid:16545804. http://dx.doi. org/10.1016/j.exppara.2006.02.001

Homan WL, Vercammen M, De Braekeleer J, Verschueren H. Identification of a 200 to 300 fold repetitive 529 bp DNA fragment in Toxoplasma gondii, and its use for diagnostic and quantitative PCR. Int J Parasitol 2000; 30(1): 69-75. http://dx.doi.org/10.1016/S00207519(99)00170-8

Howe DK, Honoré S, Derouin F, Sibley LD. Determination of genotypes of Toxoplasma gondii strains isolated from patients with toxoplasmosis. JClin Microbiol 1997; 35(6): 1411-1414. PMid:9163454. PMCid:229759.

Marques FAC. Transmissão vertical do Neospora caninum em fêmeas de corte (Bos indicus) abatidas em frigorífico / Francisco Augusto Coelho 
Marques. - Londrina. 2009. 81f. Tese (Doutorado) - Universidade Estadual de Londrina, Londrina.

Müller N, Zimmermann V, Hentrich B, Gottstein B. Diagnosis of Neospora caninum and Toxoplasma gondii infection by PCR and DNA hybridization immunoassay. J Clin Microbiol 1996; 34(11): 2850-2852. PMid:8897199. PMCid:229420.

Oliveira FCR, Da Costa AJ, Sabatini GA. Clínica e hematologia de Bos indicus, Bos taurus e Bubalus bubalis inoculados com oocistos de Toxoplasma gondii (Apicomplexa:Toxoplasmatinae). Cienc Rural 2001; 31(4): 621-626. http://dx.doi.org/10.1590/S0103-84782001000400010

Opsteegh M, Teunisa P, Mensink M, Züchner L, Titilincu A, Langelaar M, Van Der Giessen J. Evaluation of ELISA test characteristics and estimation of Toxoplasma gondii seroprevalence in Dutch sheep using mixture models. Prev Vet Med 2010; 96(3-4): 232-240. PMid:20637514. http://dx.doi.org/10.1016/j.prevetmed.2010.06.009
Opsteegh M, Teunisa P, Züchner L, Koetse A, Langelaar M, Van Der Giessen J. Low predictive value of seroprevalence of Toxoplasma gondii in cattle for detection of parasite DNA. Int J Parasitol 2011; 41(3-4): 343-354. PMid:21145321. http://dx.doi.org/10.1016/j. ijpara.2010.10.006

Pena HFJ, Gennari SM, Dubey JP, Su C. Population structure and mouse-virulence of Toxoplasma gondii in Brazil. Int J Parasitol 2008; 38(5): 561-569. PMid:17963770. http://dx.doi.org/10.1016/j. ijpara.2007.09.004

Su C, Zhang X, Dubey JP. Genotyping of Toxoplasma gondii by multilocus PCR-RFLP markers: A high resolution and simple method for identification of parasites. Int J Parasitol 2006; 36(7): 841-848. PMid:16643922. http://dx.doi.org/10.1016/j.ijpara.2006.03.003

Yai LEO, Ragozo AMA, Soares RM, Pena HFJ, Su C, Gennari SM. Genetic diversity among capybara (Hydrochaeris hydrochaeris) isolates of Toxoplasma gondii from Brazil. Vet Parasitol 2009; 162(3-4): 332-337. PMid:19375864. http://dx.doi.org/10.1016/j.vetpar.2009.03.007 